\title{
THE U.S.A. - LIBYAN CONFRONTATION
}

\author{
Prof. Dr. Türkkaya ATAÖV \\ Chairman, International Relations Section, \\ Faculty of Political Science, \\ Ankara University, TURKEY.
}

One needs to adhere to standards of objectivity while assessing foreign governments and their policies. The appraisals of the Administration of President Ronald Reagan and the reporting on the Socialist People's Libyan Arab Jamahiriya by the U.S. mass media are based on stereotyping. The Jamahiriya, the Libyan Arab people and its leader Muammer al-Kaddafi have increasingly become targets of the Reagan Administration as well as widespread mass media attacks. Neither the U.S. Government, nor the U.S. information industry gives, on the other hand, an accurate picture of the world it purports to describe. Information, as much as it influences behaviour, is also a means of control. For instance, the same government and the same media had portrayed several liberation movements as "terroristic".

Although this paper does not claim that Libya is problem-free or that its leadership cannot be critized, it, nevertheless, merits a balanced perspective in a changing world, a fairer press coverage. This paper will attempt to show the links of Libya's foreign policies with historical expcrience, the significance of domestic developments, the clash with U.S. irterests in oil, New International Economic Order, Arab unity, Palestine and Chad.

\section{A LIBYAN IDEOLOGY:}

The Libyan leadership articulated an ideology ${ }^{1}$ with strong Libyan antecedents as well as similarities with other Arab revolutionary thought. What should interest us here is not the appraisal of that ideology, but the fact that the Libyan Arab people are now aware of the past savage

I An appraisal in English: Ronald Bruce St. John, "The Ideology of Mu'ammer al-Quadhdhafi: Theory and Practice," International Journal of Middle East Studies, New York, Vol. 15, No. 4 (1983), pp. 471-490. 
exploitation and have started to fundamentally change their destiny. It is appropriate here to remember that even the early official statements of the Revolutionary Government revealed an impatience to thoroughly transform the Libyan society. In his first major address on September 16, 1969, a fortnight after the Revolution (delivered on the thirty-eighth anniversary of the martyrdom of Omar Mukhtar), Kaddafi outlined the m:ajor themes of the ideology which he was to develop soon.

Libya had seen other courageous political movements in the past. The Sanusi movement of the Nineteenth Century, for instance, spread a religious and social system from Cyrenia to different parts of north Africa. But the monarchy not only failed to bridge the division between the urban minority in Tripoli and the tribal hinterland, but even accentuated it by allowing oil wealth to further divide the Libyans into "Westernized haves" and the traditional "have-nots".

In the now-famous Benghazi address on September 16, 1969, on the other hand, Kaddafi said that the people were "the leader" and that the individual would be liberated from "degradation, oppression, ignorance... slavery... poverty and backwardness." One has to concede that in terms of overturning the old order, the Libyan Revolution is perhaps "one of the most radical the world has seen". Kaddafi was himself born "in a tent" in Sirte. ${ }^{3}$ In an interview with Le Figaro, reprinted in al-Yawm, October 1, 1969, he stated that his parents "still live in a tent."

"Libyan brand of Arab socialism" was initially based on the Egyptian example, but has certainly gone beyond it. It is not Marxist. It shares a number of characteristics with the other variaties of "Arab socialism". But even an official Washington publication describes it with roots in local history and custom. ${ }^{4}$ In an Ajdabiyah address on September 18, 1969, an RCC members stated that the principals of the Revolution were "not imported". Nascent ideology gained legal expression in the interim constitutional proclamation of December 11,1969, which summarized the goals of the Revolution as freedom, socialism and unity (hurriyah, ishtirakiyyah va'l vahde).

Kaddafi conceives of freedom as three inter-connected concepts: the emancipation of the citizen from want, ignorance and injustice; the libera-

2 Jacques Roumani, "From Republic to Jamahiriya: Libya's Search for Political Community," The Middle East Journal, Washington, D.C., Vol. 37, No. 4 (Spring 1983), p. 151.

3 Mirella Bianco, Kadhafi: Messager du désert, Paris, Stock, 1974, p. 12.

4 Richard F. Nyrop et al., Area Handbook for Libya, and ed., Washington, D.C., Government Printing Office, 1973, p. 245. 
tion of Libya from the imperialists, the neo-colonialists and the reactionaries; and the emancipation of the entire Arab world. He refers to "socialism" as a solution to man's economic problems. Libyan brand of socialism is also "nationalistic", which may be typical in an area where socialism and nationalism are found together. Point 3 of the five-point declaration of the RCC stated on September 1, 1969, that "socialism sprang from the heart of the nation". It was the "socialism of Islam"; merely heading towards a "society of equality and justice". There would be "no imitation of any foreign system, whether it be the Soviet Union or another country." The spirit of Islam was "not incompatible with socialism." But it was also "a necessity for the removal of the overwhelming majority of the people from poverty." On November 7, 1969, Kaddafi said in Tobruk: "In other countries, people were able to land a man on the moon. Here, under client-monarchy and colonialist bases, we live in tents without electricity or even water".

For about four years, Kaddafi differentiated between domestic and foreign capitalists and encouraged indigenous capital. When a three-year plan was announced in 1973, there was sizable private sector in Libyan economy. The first five-year plan of 1976 envisioned an annual increase of 25 percent in industrial output: In the second five-year plan of 1981, self-sufficiency in industrial production became the goal of the régime. It was after 1975 that Kaddafi's theories were expressed in terms of laws tightening control over private enterprise. This action went hand in hand with a "cultural revolution" (al-thawra ath-thaqafiyya) that created the "popular committees" (al-lejan ash-sha'abiyya) supervising the country's administration. As the committee system expanded, the Arab Socialist Union (ASU) came to an end. In 1975, the General People's Congress (al-mukhtamar ash-sha'ab al-a'am) was established, with Kaddafi as its Secretary-General (al-amen al-a'am), as the umbrella organization for the popular committees. This was how Kaddafi interpreted the following Koranic phrase: "They shall run their affairs by consultation."

By the time the second part of the Green Book (al-Kitab al-Ahbar) was published in 1978, the economy had already undergone considerable change. With the announcement of Resolution Four by the General People's Congress in March 1978, all Libyans were given the right to own homes. In September 1978, workers rushed to take over about two-hundred

\footnotetext{
S Kaddafi on September 16, 1969.

- Al-Maghribi, in an interview with AFP, reprinted in al-Yawm of September 18. 1869.

7 Kaddafi, in an interview with al-Haqiqat on October 2, 1969.

8 Kaddafi in Sabha on September 22, 1069.
} 
enterprises. In May 1980, all currency in denominations larger than one Libyan dinar was declared void, and citizens had a week to exchange their money. The maximum exchange was set at one-thousand dinars. At the beginning of 1981 , it was announced that the state would take over by the end of the year all import, export and distribution functions. Private retail trade has stopped. There are now a series of state-run supermarkets in all cities and towns, replacing the private sector. The religious endowment lands (vaqf) were also expropriated. In other words, wealth, either as land, capital, housing or business, is significantly redistributed. No doubt, the practice of socialism in Libya has been more fundamental than that of its neighbours.

The replacement of the Libyan embassies by the people's bureaus (al-mektab ash-sha'abe) in late 1979 and early 1980, was another manifestation of search for new forms of governance based on popular participation. In the mid-1970s, a People's Army supplemented the regular armed forces with a nation of reservists.

Kaddafi's beliefs has many things in common with the ideologies of other Arab revolutionary movements. They may be described as heterogeneous, but they are committed to radical changes in the direction of modernization, especially in a political climate in which the equation of development with Westernization is rejected. The applications of Libyan socialism in terms of property rights and wages separate Kaddafi from Nasser and the Ba'th. His ideology justifies utilizing Western technology to operate an oil economy without going through an alienation that may come with it. The Revolution devoted a large part of the oil income to the creation of a public sector. ${ }^{9}$

\section{THE LESSONS OF HISTORY:}

The foreign policy pursued by Libya has been influenced by the history, ${ }^{10}$ geography and social patterns of what was Tripolitania, Cyrenaica

9 Kaddafi, in an interview' with al-Hawadith (Beirut), reprinted in al-Ra'id on October 11, 1969.

10 There is ample material in Tripoli and Benghazi as well as in the Ottoman archives in Istanbul on the history of Libya. The Center for Libyan Studies (Tripoli), among others, is searching, gathering and classifying records that illuminate the past. An important source on historiography: Rifaat Abou-EI-Haj. "An Agenda for Research in History: the History of Libya Between the Sixteenth and Nineteenth Centuries," International Journal of Middle East Studies, New York, Vol. 15, No. 3 (August 1983), pp. 305-319. Muhammed al-Usta, of the Libyan Archives (Darulmahiuzat, al-Saray al-Hamra) indicates that the records: for Tripoli are available from the beginning of the Seventeenth Century. It may be useful to remind here that Tripoli had welcomed the Ottoman Turks in 1555 . 
and the Fezzan. That country had a difficult experience with colonialism and neo-colonialism until the 1969 Revolution. The Libyans have a feeling of mistrust of the West, rooted in the Arab (and Muslim) encounter of a particularly brutal form of imperialism. Libya's experience beginning with the Ottoman War of 1911, has provided its people with depressing thoughts concerning foreign behaviour in international politics. The pro-Western policy cannot be popular there. For Libya, the United States is a main target, because it symbolizes the Western World and supports Israel. ${ }^{11}$ Italian colonialism, then fascism, followed by British, French and American military use of Libya provided the unforgettable historical background to that country's criticism of the revived open door policies exhibited by certain great powers and the agreeing regional states. The Libyan people consider it entirely legitimate to work for closer ties with the Arab, Muslim and African countries and the dwindling of Western influence in the world.

Libya was the last country to be colonized in North Africa and the first to be decolonized. Italian occupation was a kind of settler colonialism, which some Libyans liken to South Africa and Israel. It was marked by bloody wars and a few decades of exploitation. ${ }^{12}$ The last phase of Italian supremacy was fascist rule, which sought to redefine values in its own framework. It cannot be denied that the Libyan people have developed an anti-fascist and an anti-Nazi stand.

The people have seen the collaboration between the Italian invaders and some privileged Libyans who wanted to preserve their status. The people have realized in their past a general mobilization of tribal forces, coordinated by the Sanusi leader Ahmad al-Sharif and a group of Ottoman Turkish officers, ${ }^{13}$ who chose to stay in Libya. In 1915, they defeated the Italians, who were forced to withdraw to three centers on the coast. Contrary to the British-supported Arab revolt in Mecca against the Ottomans, the Sanusi movement initially acted with the Turks in an effort

as liberators from the Christian Spaniards and the Knights of Malta, and the Turks and the Libyans fought against Italian colonialism shoulder to shoulder in 1911. Two international seminars have been held cone in Ankara and the other in Tripoli) to investigate the history of Libyan-Turkish relations. Hacettepe Üniversitesi, Türk-Arap İlişkileri: Geçmişte, Bugün ve Gelecekte, Ankara, 1979.

1 There was even a direct confrontation with the U.S. Navy in 1804. ICuching and Appleton,I History of the War Between the United States and Tripoli, Mass., 1808; reprint: Tripoli, Fergiani, 1970.

13 Ahmed M. Ashiurakis, A Concise History of the Libyan Struggle for Freedom, Tripoli, 1976.

13 Orhan Koloğlu, Mustafa Kemâl'in Yanında İki Libyalı Lider: Ahmet Şerif - Süleyman Baruni, Ankara, Libya Halk Burosu Kültür Merkezi, 1981. 
to protect Muslim lands from the onslaught of Western imperialism. A Sanusi Amirate in Cyrenaica being established, Ahmad al-Sharif received a mandate from the Ottoman Government to proceed with a jihad against all foreigners in North Africa. There was also a "republic" in Tripolitania. established in 1918, which demanded that colonial Italy open negotiations for independence. The indigenous administration in Tripoli, nevertheless, extorted some internal autonomy, as originally demanded from the Italians by the Turks, who were forced to withdraw on account of a general pressure on the Ottoman Empire. The fascist era in Italy, however, brought total domination countered by the heroism of Omar Mukhtar.

While the new Fascist government in Rome tried to control its North African territory inch by inch in one of the most brutal colonial wars of the Twentieth Century, it faced, nevertheless, violent resistance. The Libyan people have experienced concentration camps, poisoned wells, bombardment of civilian settlements and the hanging of resistance fighters. If there are now in the American press racialistic statements describing Libyans as "less than their chicken or goats", one might as well know that the Libyan population had been halved, during the colonial era, by war casualties, emigration and famine. ${ }^{14}$

Libya was the first state (1951) to emerge under the auspices of the United Nations. There is evidence of nationalism and anti-Western feeling even under the monarchy. In 1951, Libya was economically dependent on the budgetary support of Britain, the United States and France. On July 29,1953 , a twenty-year treaty of friendship and alliance was signed with the United Kingdom whereby the latter received extensive jurisdictional and extraterritorial rights. On September 9, 1954, the Governments of Libya and the United States also signed a treaty of friendship and mutual support, securing the latter military base rights. It was scheduled to last until December 24, 1970. The Kingdom having become dependent on income from British and American air bases, its anti-colonialist credits

"The experiences of Italian colonialism and the Second World War have shaped tho personality of the contemporary Libyan. The legacy is deeper than the West is prepared to understand. For instance, several thousand civilians have lost their lives or have been gravely injured, on account of the 2 to 14.5 million anti-tank mines, laid in Libya during the campaign in North Africa by the bolligerents Germany, Italy ard the United Kingdom. Furthermore, a considerable part of the country cannot bo opened for agricultural or inciustrial purposes as long es this danger is not totally eliminated. The danger to the local population and the impediments to the economic development of the country have been inherited from the colonial times. Karl Josef Partsch, "Remnants of War as a Lcga! Problem in the Light of the Libyan Case," American Journal of International Law, New York, Vol. 78, No. 2 (April 1984), pp. 386-401. 
were quickly used up. The monarchy, nevertheless, sought to minimize foreign impact on Libyan socio-political structures and underlined that it was pursuing a policy of non-alignment.

The Libyan monarchy had a deficit economy before oil exports changed its economic fortunes. Oil, discovered in 1959, changed the emphasis of the monarchy's foreign policy. On February 23, 1964, Libya formally requested a reconsideration of the status of the military bases. A year later, the United Kingdom began evacuating troops from Tripoli, and the U.S. Government agreed to withdraw from Wheelus Field. The monarchy threatened to shut down this base and briefly stopped oil production, to keep abreast with the popular reaction to the Israeli aggression in 1967.

However, a new phase of Libyan history began on September 1, 1969.15 The Revolutionary government has been able to put past legacies into effect. Libya has been united for the first time in its history. The hinterland is now a part of national life. In 1951, two distinct political legacies, namely, the Republic at Tripoli and the Sanusi Amirate, had joined in a reluctant partnership. These two contending legacies persisted until 1969. Not only the former tribal people, but also all citizens later developed the feeling of direct participation in the affairs of their society.

The Revolutionary leadership had to return to the theme of injustice and indignity that the Arabs had suffered in Western hands. Libya became opposed to turning itself and its neighbours into entrepots for American or other foreign interests. The RCC, that planned and executed the Revolution, emphasized that the new republic was an Arab state, that it would be non-aligned and that it; would be against all forms of colonialism and imperialism. The Revolutionary government expanded many policies initiated by the monarchy. For instance; the Libyan people had supported the Palestinians since 1947, and with the discovery of oil, even the monarchy had sought to limit Western influence. But the policies of the Revolutionary government were in many ways radical departures from those of the monarchy. It was the first Arab state to promote Arab unity. Correctly observed by Nathan Alexander, ${ }^{16}$ "advocacy by the rich of union with the poor was a complete reversal of a long-standing pattern in the Arab world." For the first time, the government had combined oil and pan-Arabism, which had been at odds in recent past. Part 1 of the Constitutional Proclamation of December 11, 1969, described Libya as an Arab

15 The -Kingdom of Libya became the Libyan Arab Republic on September 1, 1969 and the Socialist People's Libyan Arab Jamahiriya on March 2, 1977.

16 Nathan Alexander IRonald Bruce St. Johnl, "The Foreign Policy of Libya: Inflexibility Amid Change," Orbis, Pennsylvania, Vol. 24, No. 4 (Winter 1981), p. 845. 
democratic republic whose people constituted part of the "Arab Nation" (al-Umma al-Arabiyya) and whose objective was Arab unity. In the first Proclamation of the Republic on the 1st of September, 1969, the makers of the Revolution stated that they wished to revive their heritage and "revenge an honour wounded and a right usurped". They referred to the "holy war" of Omar Mukhtar and to the struggle of Ahmad al-Sharif. The leadership began pressuring the British and the American Governments for an early termination of the agreement. As "one of the reasons of the Revolution," Kaddafi, in a address in Tripoli on November 28, 1969, singled out "the foreigner" (al-ajnabi), who was "in control everywhere".

Non-aligned Libya considered itself as part of the Middle East and Africa. In Africa, early Libyan policy concentrated on opposition to colonialism, neo-colonialism and on the undermining of the Israeli presence. British forces evacuated Wheelus Field in 1970. On February 5, 1972, all agreements between the U.S. and Libya made before the 1969 Revolution were terminated. The Italian-owned assets were nationalized in mid-1970. Libya withdrew its reserves from British banks and nationalized all British Petroleum Company assets in 1971. ${ }^{17}$. In the early 1970's, the RCC pursued a policy of neutralizing the Mediterranean. It felt that the use of the air and naval installations in Malta by the United Kingdom gave excessive influence to foreign powers. The Libyan people started opposing racism with every weapon. For instance, workers at the oil port of Hariqa refused to help the American tanker Atlantic Courage lift Libyan oil when they found out that the tanker had had dealings with the South African racist régime. In an effort to isolate Israel in Africa south of the Sahara, Libya felt obliged to support governments like those of President Idi Amin of Uganda ${ }^{18}$ and Emperor Jean-Bedel Bokassa in the Central African Empire. While Libyan leadership aimed to achieve "complete sovereignty" (al-istiqlal at-tam), as so expressed by Kaddafi in a Tripoli meeting on November 28, 1969, it still hoped to preserve the friendship of the American and British peoples. The Libyan Government, nevertheless, maintained close commercial relations with the West, selling oil in return for technology. Libyan university students generally went to the United States (and not to the Soviet Union) for education.

Anti-colonial actions in the economic life of the country began within a fortnight of the seizure of power when the RCC announced that the

17 March 28 (the day the British evacuated the al-Adem base) and June 11 (the day the Americans evacuated Wheelus Field) are now official holidays observed annually by popular festivities. October 7, the day in 1970 the Italian assets were nationalized, is also a holiday.

${ }^{18}$ Amin himself was finally forced into exile in Libya. 
foreign banks were expected to form Libyan joint stock companies with at least 51 percent of the shares owned by the government. In late 1970 and the beginning of 1971 , the government negotiated major concessions from the oil companies. By the fourth anniversary of the Revolution, nationalization had become widespread. ${ }^{19}$

Parallel with the drive towards more equality within the Jamahiriya, the Libyan leadership has pursued policies for a New International Economic Order (al-Nitham al-iqtisadi al-jadid baynash-shuub). The former metropolitan countries are largely responsible for the poverty, backwardness and the plight of the Third World, including Africa. Through the mechanism of transfer prices and monetary machinations the international monopolies have taken out of the Third World sums far exceeding the value of all aid. This unequal status is forcing them to fight for a revision of their status. The young states of Africa are waging a struggle for the establishment of a New International Economic Order. Libya among them insists on a reorganization of the entire system. It demands fair prices when exchanging raw materials for finished goods, full access of their goods to Western markets, the abolition of trade restrictions and better terms for obtaining technology.

This policy in no way runs counter to those of the U.N. Economic Commission for Africa and Organization of Africa Unity. The Revised Framework of Principals for the Implementation of the New International Economic Commission for Africa, adopted by the U.N. Economic Commission for Africa in 1977, is a program of action for the African countries. And the 15th Session of U.N. Economic Commission for Africa in 1980 specified the objectives and tasks of Africa's economic development for the 1980's. This session adopted the Plan of Action for the Implementation of the Monrovia Strategy for the Economic Development of Africa (1977), later endorsed by the Extraordinary Session of the Assembly of Heads of State and Government of the O.A.U. in Lagos. The Plan of Action enumerated that (a) Africa's huge resources must be applied principally to meet the needs and purposes of its people, (b) Africa's almost total reliance on the export of raw materiais must change, (c) Africa must cultivate the virtue of self-reliance and (d) Africa must mobilize her entire human and material resources for her development. Libya has not differed from this strategy of development; it has, moreover, vigorously pursued its implementation.

19 For various stages of the Revolution, see: Omar I. El Fathay and Monty Paimer, Political Development and Social Change in Libya, Lexington, Mass., Lexington Books, 1980. 


\section{U.S. CONFRONTATION:}

According to President Reagan and his team, the "fact" is that the conflict with the Soviet Union is the supervening structural feature of the Middle East and Africa. The American public is not yet aware of the extent to which Arab nationalism or Islamic resurgence or quest for equitable relations impose a degree of tolerance in the face of a challenge that rejects "values" dear to President Reagan. Will it be possible for the U.S. Government to overcome the wide gap in cultural understanding between "them" and "us"?

The publication of an article in the Foreign Affairs ${ }^{20}$ journal, on how U.S. foreign policy ought to be conducted coincided with the inauguration of Ronald Reagan as President of the United States.

The "hawks" had started scoring success in the last months of the Ford Administration. The Carter Administration had agreed to increase U.S. military spending. And in the run-up to the 1980 elections, it was Reagan who responded favourably to the agenda drawn up by the hawks. Reagan's general approach towards detente was mirrored in his statements. on the Middle East. Not only he placed alliance with Israel above any contact with the Arabs, but also Israel was, in his eyes, the military offset to the Soviet Union.

Born into a "damned poor" home, the converted Reagan of the 1960's began fund-raising for the national public relations director of the John Birch Society, Congressman John Rousselot. Ronnie Dugger ${ }^{21}$ shows that no president in modern times has so effectively undermined minorities, labor unions, social security, civil liberties, consumer protection, safety in the work-place, small business and the needs of farmers. He opposed every major civil rights bill and halted federal enforcement of anti-discrimination laws. Reminding his personal Presidential hero, Calvin Coolidge, Reagan slashes human needs programs as "budget savings", providing relief for those in the higher tax brackets because of their "greater ability" to invest. $\mathrm{He}$ is committed to the arms race, nuclear superiority, first strike capability and to the belief that a nuclear war can be fought in such a way as to allow the U.S. to force the Soviet Union to seek earliest termination on terms favorable to the U.S. The President gives the impression that he seeks to return to the era of "Red-scare" at home and abroad.

20 Daniel Yankelovich and Larry Kaagan, "Assertive America," Foreign Affairs, New York, Vol. 58, No. 3 (Spring 1981), pp. 696-713.

21 Ronnie Dugger, On Reagan: the Man and His Presidency, New York, McGrawHill, 1983. 
In a number of important issues, a "free people" are behaving with Pavlovian conformity. ${ }^{22}$ Is the United States still a land governed by the people? If two percent of the population owns or controls over two-thirds of the nation's wealth, then the "American way of life" is really a matter of power, and those who own much of the information industry as well also dictate what is reported and what serves their interests. The American welfare state has given way to a succession of multinational oligopolies in banking and industry.

Consequently, some American writers ${ }^{23}$ view with alarm the events that they attribute to the "ineptitude" of leaders charged with the conduct of U.S. foreign policy. For instance, some ${ }^{24}$ believe that the revolution in Iran could have been averted by the timely use of repressive military force' on the part of the Shah, and that consequently its occurrence was due to some failure of the U.S. Government in terms of tactical errors, lack of information and indecisiveness. This outlook is the same as that of the CIA, when it intervened in Iran back in 1953. The "defects", on the other hand, are more deeply imbedded in the American form of governing, domestic and foreign, which would like to stop the clock. The press sees the Middle East and African developments through the prism of powerful American interests, centering on oil, Israel and strategy. Although the U.S. possesses large reserves of a great many essential minerals, a number of critical items are obtained from other countries - such as oil from the Gulf, bauxite from Jamaica, cobalt from Zaire or tin from Malaysia. In addition to its dependence on Arab oil, the U.S. is obsessed with WestSoviet confrontation, which poses a threat to world peace.

In the Middle East, the United States is categorically committed to the preservation and the defense of Israel and its interests. ${ }^{25}$ In spite of differences and even tensions between the present Israeli Government and the Reagan Administration, there is great affinity between the two. The

22 Loyle Hairston, "U.S. Media: the Information Opiate," Freedomways, New York, Vol. XXII, No. 3 (1982), p. 139.

23 Joseph Churba, The Politics of Defeat: America's Decline in the Middle East, New York, Cyrco Press, 1977; Wilbur Crane Eveland, Ropes of Sand: America's Failure in the Middle East, New York, W.W. Norton, 1980.

24 Michael Ledeen and William Lewis, Debacle: the American Failure in Iran, New York, Knopf, 1981; Barry Rubin, Paved with Good Intentions; the American Experience and Iran, New York, Oxford University Press, 1980.

25 Citing a CIA report to President Truman, author W.C. Eveland suggests that little has changed in thirty years in the Middle East. This report had emphasized the centrality of the Palestinian piobicm and noted that Israeli local power superiority and ambitions prevented stabilization of the region. Eveland, op. cit., p. 358. 
Reagan "peace" plan has rejected the claims of the Palestinians to separate, independent statehood. The narrow issue that separates the United States and Israel is what sort of control Israel will continue to enjoy on the West Bank and in Gaza and what status Israeli settlers will have in these areas. Daniel Pipes correctly states that Israel has what may be termed "the highest percapita fame quotient in the world". ${ }^{26}$ No other country of comparable size commands even a fraction of its familiarity in the U.S. He adds: "But... the emphasis on Israel fundamentally distorts the way Americans perceive the Middle East."27 Israel offered the United States access to bases needed for the defence of American interests in the Gulf, in the hope of solidifying Washington's pro-Israeli stance. The U.S. responded first in September 1981 (the U.S.-Israeli strategic cooperation agreement) and then in November 1983 (a military and political cooperation agreement).

In respect to Africa, the U.S. does not want to abandon this continent to the Africans. For years, the public was told that the United States had no African policy - while American corporations were investing billions of dollars in South Africa, while the U.S. Government was supporting Portuguese colonial wars and while the CIA was roaming in several African countries. Under Reagan, the U.S. concentrated in consolidating its front on the eastern border of northern Africa. To this end, it continued to work actively at destabilizing those régimes opposed to the aims of the U.S. Within this context, Libyan foreign and domestic policies have become subjects of fervent debate in the United States during the Reagan Administration. Some American writings, ${ }^{28}$ however, concede that much of the debate on Libya took place with little or no appreciation of the historical context and the local phenomena in Libya. Differences in world outlook and interest are at the heart of the growing impasse between the U.S. and Libya. Reagan's policy towards Libya may be described as "provocative". ${ }^{29}$ The U.S. has been an enemy of Libya since 1969. The new Libyan régime had dismantled American bases, nationalized oil companies and pursued a policy of non-alignment. Ever since the Libyans forced the Americans out of their country, Libya has been a thorn in the American side.

${ }^{26}$ Daniel Pipes, "The Media and the Middle East," Commentary, American Jewish Committee, New York, Vol. 27, No. 6 (June 1984), p. 29.

27 Ibid., p. 30

28 Lisa Anderson, "Libya and American Foreign Policy," The Middle East Journal, Washington, D.C., Vol. 36, No. 4 (Autumn 1982), pp. 516-534.

29 Ronald Bruce St. John, "The Ideology of Mu'ammer al-Qadhdhafi," op. cit., p. 479; _ . "Libya's Foreign and Domestic Policies," Current History, Vol. 80. No. 470 (December 1981), pp. 426-427. 
In the eyes of Libya, Big Business, which dominates American politics, is guided by narrow and selfish interests. Just as there is practically no crime left uncommitted in the United States, attacks on countries of the Middle East and America and subversive operations have become standard actions of the Reagan Administration. Libya feels that the U.S. Administration has been resorting to the use of force ever more frequently, modifying only the forms of its use depending on circumstances. The U.S. arms and dispatches numerous bands which terrorize the peaceful population. This is sometimes done to the accompaniment of threats to use U.S. armed units. Such threats are at times backed by the concentration of U.S. naval forces near the shores of these countries and flights of military aircraft over their air space.

Libya, which is "radical" in its support of forces seeking change in the world system, has no neє d of U.S. "aid". Other "radical" Arab countries, such as Syria or South Yemen, do not have the economic independence to challenge the U.S. Hence, Libya is a target of the American Government. There have been frequent calls for the overthrow of the Libyan Government by force. Libya is no country's pawn. Libya feels that, under the pretext of opposing Soviet ascendancy, the U.S. tries to strengthen its own control over Third World nations and to hold back the tide of change. Since the 1969 Revolution, Libya has always been against foreign warships to enter Libyan territorial waters. It has not permitted the Soviets to use its ports or airfields. The only Soviet naval visit took place in May 1969 when the King still ruled.

By 1972 American diplomatic representation in Libya had been reduced to the level of a chargé d'affaires. Kaddafi participated in the oil boycott of the United States following the 1973 War, broke with Egypt's Sadat as he moved closer to the United States and nationalized several American oil companies when the U.S. tried to establish a consumers' union in 1974. By 1975, the United States refused to deliver military transport planes ordered and paid for by Libya. In the last month of 1979, a group of Libyans attacked the American Embassy in Tripoli and burned it. Following the announcement of a "hit squad" allegedly sent by Kaddafi to assassinate Reagan, the U.S. Government asked all Americans to leave Libya and banned high-technology exports to that country. In September 1980, two U.S. spy-planes (a C-135 plane escorted by an F-14 fighter) were sent to the very edges of Libyan airspace. An additional two Navy F-14 planes were launched from the John F. Kennedy aircraft carrier when Libyan planes intercepted the Americans. With the aim of provoking a Libyan response to justify full-scale invasion, the U.S. Sixth Fleet violated Libyan sea and air space for four days beginning with March 10, 
1981. In August 1981, U.S. naval maneuvres in the Gulf of Sirte ${ }^{30}$ precipitated a dogfight in which one U.S. and two Libyan planes were shot down. On May 6, 1981, the U.S. State Department expelled all members of the Libyan People's' Bureau in Washington, D.C., under the pretext of alleged Libyan role in Soviet-inspired "international terrorism". Libya considered this act as part of a plan to discredit the country in the eyes of the world community. ${ }^{31}$ With the closure of the Libyan People's Bureau in Washington, D.C., conditions for a quiet dialogue have apparently disappeared.

\section{THE SOVIET “CONNECTION":}

The policy of non-alignment means that Libya will not join any alliance of non-Arab powers..$^{32}$ Its Soviet connection has been limited by purchase of arms. The ideological influence of the Soviet advisors working with the Libyan Armed Forces is nil. The Soviet Union has not been permitted to use any Libyan port or refuelling facility. Soviet weapons were first delivered to Libya in July 1970. Libya has also bought arms from France and Italy, but has been refused by the United States and Britain. Soviet arms transfers to countries like Libya and Syria have been cited by the Reagan Administration as partial justification for an expanded U.S. military presence in the Mediterranean. It is true that there is a Soviet presence in Afghanistan, that the Soviets have a treaty with South Yemen, that about 25 of its divisions have been placed along the Iranian border and that it has more than thirty warships in the Indian Ocean. ${ }^{33}$ In comparison with the U.S., the Soviet Union is militarily better prepositioned and enjoys geographic proximity to the region. But the American fleet in the Indian Ocean is indeed more than a match for the Soviet fleet there. Although there are frequent charges that the Soviet Air Force would use Libyan bases in times of crises, ${ }^{34}$ it is the U.S. that hopes to use the bases it has obtained from Egypt, Oman, Somalia, Sudan and Kenya. The "strategic consensus" with the "moderate" Arab countries would serve that purpose. "Soviet arms transfers... may not threaten U.S.

${ }^{30}$ Saadi Youssef, L'Affrontation arabe-americain du Golfe de Sirt, Nicosie (Chypre), Al-Moukif al-Arabi, 1982.

${ }^{31}$ Louis Eaks, ed., From El Salvador to the Libyan Jamahiriya, London. Third World Reports, n.d., p. 7.

32 Although Kaddafi is reported to have said in September 1981 that it was time for Libya to ally with one of the super-powers, he never repeated this statement.

${ }^{33} \mathrm{Xu}$ Shan-Nan, "The Reagan Administration's Middle East Policy," Survival, London, Vol. XXVI, No. 3 (May-June 1984), p. 109. The author is a specialist in Middle East Affairs at the Institute for International Studies in Beijing.

s4 For instance: International Herald Tribune, March 4, 1881. 
interests as much as the Reagan Administration believes." ${ }^{35}$ Statistics on the arms trade can and do show both the United States and the Soviet Union in the first place. While a U.S. State Department study indicates that the Soviet Union leads in military sales to the Third World, ${ }^{36}$ a U.S. Congressional Research Service, using different criteria, places the United States in the lead. ${ }^{37}$ The 1982 fighting in Lebanon ${ }^{38}$ demonstrated that U.S. equipment given to Israel outperformed Soviet equipment given to Syria. No development in 1983 had so great an impact on American policy objectives as Syria's resurgence in the region..$^{30}$ Defeated by Israel in the Summer of 1982, President Hafez Assad turned to the Soviet Union, which provided him with $\$ 2.5$ billion worth of equipment or double what had been lost in the 1982 war. The Arab countries see Israel as the main threat not the Soviet Union.

On the other hand, which nation has become a member of the Soviet bloc because it has bought Soviet aircraft, missiles or artillery? Nasser was the first Third World leader to receive extensive arms from the Soviet Union, which has not regained its position in Egypt since his death. Arms aid has not given the Soviets any measure of political influence in Iraq. Even today, Syria maintains its distance despite a continuing need for weapons. In the face of evidence, the allegation that Libya is anyone's "satellite" does not hold water. Kaddafi displayed his own evaluation of communism and stated frequently enough (in January 1981, for example). that they were "not communists". ${ }^{40}$ It is true that Kaddafi had visited the Soviet Union in December 1976 and in April 1981. But his speech, delivered at the banquet given in his honour during the 1981 visit, raised issues that

3i Michael T. Klare, "Soviet Arms Transfers to the Third World," Bulletin for the Atomic Scientists, Vol. 40, No. 5 (May 1984), p. 26.

${ }^{26}$ U.S., Department of State, Conventional Arms Transfers in the Third World: 1972-1981, Washington, D.C., 1982.

37 U.S., Library of Congress, Congressional Research Service, Trends in Conventional Arms Transfers to the Third World by Major Suppliers; 1974-1981, Washington, D.C., 1982.

38 Larry L. Fabian, formerly Director of the Carnegie Endowment's Middle East Program, starts his article in the Foreign Affairs with the following sentence: "American peacekeeping turned into American bloodletting in 1983." Larry L. Fabian, "The Middle East War Dangers and Receding Peace Prospects," Foreign Affairs, New York, Vol. 62, No. 3 (1984), p. 632.

39 Robert G. Neumann, "Assad and the Future of the Middle East." Foreign Affairs. Vol. 62, No. 2 (Winter 1983-84), pp. 237-356.

40 Zainab Abbas and Nicholas Hyman, Responsible Reporting? Libya in the Western Press, Vol. II, London, Highclere Ltd., n. d., p. 89. 
Moscow and Tripoli differ. The assumption that the Soviets are "in Libya"41 is not only an exaggeration - it is outright untruth.

American strategists often assert that the Soviet Union plans to seize the oil reserves of the Middle East and the adjacent areas. The USSR has vast reserves of untapped oil within its own territory. Secondly, it has interest in maintaining the status quo, namely the flow of oil to the West because the denial of this important resource would only make the U.S. more pugnacious. Because it cannot confess to the American public the extent to which the international economic system is responsible for the poverty of the Third World, the U.S. is inclined to explain unrest by the "outside agitator" thesis. The argument runs that events would conform to U.S. policies if it were not for Soviet or Libyan or Cuban "agitation". Third parties, such as the Swedish Petroleum Studies Institute, have published reports rejecting the suggestion that the Soviet Union would be an importer of oil by 1985; they maintain that the Soviets would export a few million barrels per day even in 1990 .

The Soviet leader Leonid Brezhnev had proposed a security plan for the Gulf, designed to pledge the United States, the Soviet Union, Western European countries, the People's Republic of China and Japan to respect the independence of the Gulf States and their sovereign rights over their natural resources, not to use force or threaten force against the countries of the region and not to draw them into military alliances with states having nuclear weapons. The Third World countries do not accept the "logic" that if one of them does not accept American preponderance, it must be acting as a proxy of the Soviets. Libyan leadership has frequently stated it wishes both fleets, U.S. and Soviet, to disappear from the Mediterranean.

\section{THE “OUTLAW" STATE:}

The Reagan Administration's criticism of Libya's relations with the Soviets is coupled with its accusation of the Jamahiriya of fomenting international terrorism. The White House blamed the Soviet Union either directly or through client states for much of the terrorist violence that plagued the West since $1970 .{ }^{22}$ The former U.S. Secretary of State Alexander Haig claimed that the Soviet Union was training thousands of Third World terrorists in the Soviet Union, Eastern Europe and Libya. ${ }^{43}$ Libya

\footnotetext{
41 John K. Cooley, "Soviets in Libya: a New Mediterranean Power," Washington Post, March 10, 1981.

${ }^{42}$ For instance: U.S. News and World Report, May 4, 1981.

43 The Times, March 19, 1981.
} 
was accused of fomenting "coups, revolutions, separatist movements and terrorism in dozens of countries around the world". ${ }^{4}$ Western media sought to implicate Libya in several affairs, such as the Gafsa uprising in Tunisia. A CIA-retired, now free-lance writer inquires in a recent book whether Mehmet Ali Ağca, the Pope's would-be assassin, had passed on to Libya after having gone to Tunisia at the end of November $1980 .{ }^{45} \mathrm{He}$ asks: "What were the channels through which Ağca had been selected, trained, supported and guided". Was it PLO, Qaddafy, Turkish rightists or East Europeans? Or all of them?"46 Georgetown University returned a $\$ 600,000$ gift to the Libyan Government, saying that it did not want its name associated with a country that "supports terrorism". The gift was made to aid Arab studies in the university. ${ }^{47}$ It was held for one year and returned on account of strong Zionist pressure.

While labelling foreign opposition as "terrorists", the White House mounts its own military campaign abroad. It heaps threats on a number of countries, but invades Grenada and sends Marines to Lebanon. If the U.S. can charge Libya of interference in the domestic affairs of others, it should then be remembered that U.S. history, since the early decades of the Nineteenth Century, is a catalogue of interventions, the most recent examples of which range from Iran in 1953 to the current events in Lebanon, El Salvador, Nicaragua and Libya. It may be asserted that the U.S. practices terrorist methods in two ways: firstly, in terms of supporting régimes which indulge in terrorism, such as the junta in El Salvador or Zionism in Palestine, and secondly with a subversion program to destabilize the régimes it dislikes, such as the Soviet Union or Libya. It has even overthrown govermments irrespective of the fact that they might have been democratically elected - such as Allende in Chile.

The American military build-up around the Arab homeland is enorroous. It was the Reagan Administration that stepped up U.S. military penetration of the Arab world. U.S. base facilities on Egyptian territory center on Ras Banas on the Red Sea Coast. Sharm al-Sheik (Ophira), Eitam and Etzion provide the infrastructure for the intervention force dsstined for the Gulf. With the backing of the Sultan Qabus régime in Oman, the U.S. has access to the military base on Masira Island. The U.S. has also provided capital for the development of the Omani naval ports at Mutrah (near Hormuz), Salalah (near Democratic Yemen) and a smaller airfield at Seeb (also near Hormuz). It has a base at Berbera

\footnotetext{
47 Washington Post, February 22, 1981.

${ }_{45}$ Paul B. Henze, The Plot to Kill the Pope, New York, Charles Scribner's Sons, 1983, p. 10.

46 Ibid., p. 21.

${ }^{47}$ The New York Times, February 24, 1981.
} 
in Somalia. Plans also include facilities in the Sudan and Kenya. There are new military bases at Fasher in West Sudan and at Suwakin on the Red Sea, which is undergoing expansion. In Kenya, the U.S. has base facilities in Mombassa. Naval and air bases in Sudan, complementing the facilities, already, available to American troops in. Egypt, the Gulf of Aden and Oman, are within striking distance from Libya. In the Western Sahara, the Moroccan war against the Polisario is sustained by U.S. military assistance. The lure for the U.S. is phosphate discovered in $\mathrm{Bu}$ Craa in the Western Sahara.

The assertion that Kaddafi (or Libya) assists terrorists all over the world is an over-simplification. Irresponsible statements equating Kaddafi with Carlos or showing the latter in Libya failed to produce any evidence, but still helped shape opinions. ${ }^{48}$ Libyan leadership differentiated between terrorism and social change; it opposed the former, but supported specifically defined national liberation movements. Warning that terrorism put an end to the great French Revolution, Kaddafi announced that he deplored the West German Baader-Meinhof Organization and the Italian Red Brigades. Supporting Spanish territorial integrity, he opposed the demand for secession made by the Basque organization E.T.A. Being in the Middle East and in Africa, it was entirely natural for Libya to be interested in the affairs of both. What is not as natural is American or French engagement with these regions considering that both these countries are geographically far away. They, nevertheless, argue that they have vital interests in other continents. This is a dual standard, which brands Libya as "terrorist" but rewards the other two with benevolence. To portray Libya as a country of "terrorists" is an exaggeration that still needs to be proved. In reply to accusation that Libya was organizing training camps for terrorist on its own soil, Kaddafi challenged the accusers to produce the evidence. When a Pakistani plane was hijacked in early 1981 by individuals opposed to the rule of General $\mathrm{Zia}$ ul-Haq, Libya denied prior knowledge of the event, condemned it and refused the plane. Although Kaddafi favoured Irish independence from Britain, he expressed opposition to IRA terrorism. He secured the release of a French archaeologist held hostage by guerilla groups in Chad. He appealed unsuccessfully to the Red Brigades in Italy for the release of Aldo Moro. Even a CIA report concluded that there is insufficient evidence to substantiate the charge that the Soviets are fomenting international terrorism: ${ }^{49}$

The U.S. also freely speculated about a supposed Libyan military nuclear ambition. Although no evidence was produced, Libya was accused

48 "Carlos on the Shores of Tripoli," Newsweek, February 23, 1981.

49 The New York Times, March 29, 1981. 
of building atomic arsenals. There were also suppositions in the AngloAmerican press that the most likely place for Libya to obtain nuclear weapons would be the Soviet Union. Such concern contrasted with Amerucan inactivity over Israeli and South African quest for nuclear war potential. While American policy is to. let this cooperation go almost unnoticed, the whole world is following it with growing anxiety..$^{50}$

Indeed, the Atomic Energy Commission of Libya was set up in 1973. In the same year, Libya initialled an agreement with the Soviet Union for a 1,000 kilowatt research reactor. The next year, Argentina agreed to provide Libya with equipment and train chemists in the extraction and purification of uranium. In 1978, Libya made an agreement with India for university training in nuclear-plant management in exchange for oil. In 1980, Libya and the Soviet Union made another agreement for the construction of a 4,400,000 kilowatt nuclear plant. ${ }^{51}$

Libya has the right to be self-sufficient in energy when oil runs out: That country has ratified the Non-Proliferation Treaty and has been conscientious in notifying the international community of agreements that have a bearing on nuclear energy. It also has the prerogative to seek ways of keeping abreast with modern science. It is unjust to single out Libya for criticism for conceiving nuclear energy as part of its energy requirements, knowing that oil reserves are not limitless.

\section{LIBYAN OIL:}

For a decade after the discovery of oil in May 1959 at Dahra in the Dirte Basin of Libya, that country faced the rapacity of big business. Treating Libya as if it was their property, the oil companies took the lion's share. Under King Idris, the Western oil companies cheated Libya into the worst possible terms for its oil.

On September 1, 1969, 34 international oil companies were operating 137 concessions, the majority of them in the Sirte basin. The RCC set up a special committee, headed by Abdussalam Jalloud who dealt with them one by one. ${ }^{52}$ The committee first tackled the U.S. Occidental Company, which agreed to an immediate 30 cents rise to be boosted by 2 cents every year for five years. It also agreed to pay an additional 3 percent surtax on profits. Thereafter, all the other oil firms backed down.

\footnotetext{
50 Türkkaya Ataöv, The Case in South Africa, London, EAFORD, [1879], pp. 7-8.

51 Dennis Redmont, "Energy Ministry Formed: Qaddafi Move Sparks New Nuclear Fears," International Herald Tribune, January 21; 1981.

52 Nigel Ash, Libya and Oil, London, Hakima PR Ltd., 1981, p. $16 f$.
} 
Western mass media advanced false theories about the nature and causes of the oil crisis that followed the Octcber War (1973). They have placed the main blame at the door of the oil-producing countries for pursuing a policy of regulation of oil extraction and price increases. They have accused the Arabs for using oil as a political weapon to secure a settlement of the Palestinian issue. They said that the oil-producing countries were responsible for the energy difficulties in Western Europe and the Third World. They saw in it the "hand of Moscow", shifting responsibility on the shoulders of the Soviet Union as well. They argued that unless the monopolies raise the prices of oil, they would be ruined. Finally, they claimed that the oil crisis lied at the bottom of all the difficulties experienced by the Western economic system.

The "seven sisters" of the international petroleum cartel ${ }^{53}$ supply close to four-fifth of all the oil imported and of all the oil products consumed in the Western world. The cartel owns most of the refineries and the marketing network. It is these "seven sisters" and several other oil monopolies that have camouflaged the true causes of the fuel crisis. To satisfy the current needs of economic development, the available resources of the world are adequate. The shortage of energy resources in many Western countries is connected with the inflation that followed the economic decline in the United States. It is not the energy crisis that produced this decline; the crisis is only a manifestation of the decline. In this context, the oil monopolies sought to keep the prices up in order to reap superprofits. On the other hand, regulating oil extraction is the lawful right of the producing countries. Price increases are also designed to establish a normal relation between the raw material and manufactured product prices. This policy might have undermined the position of the "seven sisters" and some other monopolies, which incidentally had earlier given their blessings to Israeli aggressions against the Arabs. Some Western governments and media have blamed the Arabs for using oil as a political weapon. But the U.S. has plotted intrigues, provoked wars and conducted coups in order to preserve the status quo in oil. The oil monopolies regard the energy crisis as a boon, because it provides them with the excuse for inflating prices and raising profits. It is not the oil magnates that are ruined, but medium and small companies.

Libyan leadership has frequently stated that it wa: prepared to use oil as a weapon to serve the causes of the Arab people, in particular the causes of the Palestinians. If the West would respond to such policies by attacking the Jamahiriya, Ahmed Shahati, now Director of the Green

53.BP, Exxon, Gulf Oil, Mobil Oil, Standard Oil of California, Royal Dutch Shell and Texaco. 
Book Center in Tripoli, said in 1981: "To defend ourselves and our hónour, we would be willing to destroy all our wells and return to an economy based on agriculture". ${ }^{54}$ Western media has branded Libya as "militant" on account of the O.P.E.C. conference in Bali (Indonesia). But Libya had already announced on September 22, 1980, its decision to reduce crude oil production by 10 percent. Some other O.P.E.C. members such as Algeria, Iran, Iraq and the United Arab Emirates had also announced similar cuts. Nevertheless, Libya, along with Algeria, was identified as O.P.E.C.'s "hawks". On the other hand, non-O.P.E.C. producers like Britain and Norway gladly jumped on the O.P.E.C. band-wagon, raising their oil prices. Libya's increase of the oil prices has been within the agreed O.P.E.C. framework. Libya offered, on the other hand, special low prices to developing countries. Libya has been using oil revenue on development.

By 1980, Libya's oil revenues were over $\$ 20$ billion, but for the mid1981 to mid-1982 period they were less than half of the previous twelve months. ${ }^{55}$ Government spending on the physical and social infrastructure had, to a great extent, satisfied the rising expectations of the Libyan people. Major investments had already been made, and consolidation was timely.

One may also add here that Libya is no longer dependent on refined oil from outside. The Azzawiya refinery, which now supplies 70 percent of all oil products used in Libya, was opened in 1974. Plans have also been made for the extension of that refinery. The foundation stone of this gigantic petro-chemical development with its accompanying infrastructure was laid in mid-1980.

Western assertions that Libya has resorted to "blackmail" through oil is unsubstantiated. It is the U.S. that has long used the "food weapon" to bring the Third World countries into line with Washington's objectives. It is again the U.S. that has continued to keep open the door to vital commodities, such as oil. Libya, on the other hand, has supplied oil even to states with whose policies in the Middle East and Africa it clashed. The United States is an example.

\section{APAB UNITY AND PALESTINE:}

Quest for unity of the Arab homeland has been consistent with Libyan leadership since the overthrow of monarchy. Libyan or other Arab attempt

54 Ash, op. cit., p. 26.

5: J.A. Allen, "Libya Accommodates to Lower Oil Revenues: Economic and Political Adjustments," International Journal of Middle East Studies, Vol. 15, No. 3 (1983). pp. $377-385$. 
to merge should be viewed in a historically recurring context. For instance, in the 1940's, the Syrian Ba'th Party called for Arab unity stretching from the Atlantic Ocean to the Gulf. Similarly, the Pan-Arab ideal became a goal of Nasser, who believed that different Arab countries shared a culture on which they could build their own system of cooperation and defense. In contrast to the American view that the Middle East was a land mass defenseless in front of the Soviet Union, Nasser considered Israel, the United States and the Soviets as foreigners in the region.

With the collapse of the United Arab Republic in 1961, however, the Arabs were less optimistic about the immediate prospects of Arab unity..$^{56}$ In spite of this, Libya made repeated attempts at Arab unity even after the idea became less and less popular elsewhere among the Arabs. That country has called for unity, at different times, with Tunisia, Egypt, Sudan, Algeria, Chad, Syria and Morocco. Libya believed that the present weakness of the Arabs and Israel's triumph over them were due to their disintegration into several entities, a process sustained by the colonial powers to dominate the Arab world and exploit their resources. On September 16, 1969, Kaddafi described Arab unity, in a Benghazi address as "an inevitable necessity... decisive historical reaction to the challenges of Zionism and colonialism... necessary to protect the achievements of the Arab nation." He also stated, in an interview with al-Ayyam (Kartum) reprinted in al-Ra'id on December 6, 1969, that Libya did not have manpower to exploit its wealth and that Arab cohesion and the use of the capabilities of the other Arab peoples were inevitable. He stated that a unified Arab state in the Middle East and North Africa would probably have the veto right in the U.N. Security Council. ${ }^{57}$ This was another secret of the enmity existing between Libya and the U.S.

Several of Libyan attempts have indeed been failures. But there are difficulties facing any union. The U.S. itself once faced years of civil war threatening unity. The Western countries don't seem to be interested, however, in examining the problem objectively. Some bastions of metropolitan culture and capital seem generally hostile to the idea of Arab unity. They frequently remind, for instance, that Libya has a record of failures. They probably suspect that stronger Arab world will undermine American influence in the region. Western media frequently uses reports which give the reader the impression that quite few of the Arab governments are suspicious of merger proposals. But there are official statements

55 Fouad Ajami, "The End of Pan-Arabism," Foreign Affairs, Vol. 57, No. 2 (Winter 1.978-1978), pp. 355-373; Stewart Reiser, "Pan-Arabism Revisited," The Middle East Journal, Washington, D.C., Vol. 37, No. 2 (Spring 1983), pp. 218-233.

57 Abbas and Hyman, op. cit., Vol. II, p. 11. 
of Kuwait, Bahrain, Saudi Arabia, Qatar, Tunisia, South Yemen and the P.L.O., revealing support of the idea. After all, the African states have been committed to the ideal of unity, and the Common Market is a form of unity among a group of Western European States.

Libya and Syria (which has also been party to several unification schemes) proclaimed a merger in September 1980. Libya threatens U.S. interests in the Middle East via its merger plans with Syria. In late August 1984, "union" with Morocco, in spite of the differences in the political and the economic systems, has become a reality.

It is only natural for Libya to have differences even with the progressive Arab régimes on issues of lesser importance. For instance, Libyan support of one of the factions of Polisario, the liberation movement of the Western Sahara, damaged its relations not only with Morocco, but also with Algeria, which supported another faction. Although it is true that Libya's policies have attracted the interests of the Pan-Arabists above all, Libya desires to have good relations with every country in the region. It has united with the Moroccan monarchy, cultivated good relations with the United Arab Emirates and frequently expressed the desire to improve relations with Tunisia.

The question of Palestinian rights is central to the quest of Arab unity. In the eyes of the Libyan Government, Palestine is part of the Arab lands, and Zionism is a foreign political movement; the creators of Israel were motivated by hatred for Islam and a desire to exploit Arab resources. The Libyan Minister of Unity and Foreign Affairs, in a speech at the Arab Cultural Center as early as October 9, 1969, had declared: "He who supports the Palestine cause is a friend to the Arabs." The same person, in a statement to al-Tawrah on November 8, 1969, said that the Arabs ought to build their relations with other states on the basis of their position on this very cause.

Nothing has changed Libya's stand since 1969. Libya is still an unconditioned opponent of Zionism. That country knows that for the U.S., Israel comes first. Libya knows that an immediate consequence of Reagan's election had been the escalation of Israel's war against the Palestinians and its drive into Lebanon. Libya opposed, together with Syria, Reagan's Middle East "peace" initiative launched on September 1, 1982, and they both maintain that it is no better than the Camp David framework. Libya faces Israel not only in the Eastern Mediterranean through its close association with Syria, but also in Africa. When in 1983 American firepower struck positions in Syrian-controlled territory in Lebanon, this was the first U.S. naval bombardment in the Mediterranean since World War II. 
At the beginning of December, the U.S. launched its first direct attack against Syrian forces. Whether or not this was in response to concentrated Syrian anti-aircraft shooting at the U.S. reconnaissance jets over Lebanon, this brought not only Syrian, but also Libyan views and interest in collusion with those of the U.S. Facing Zionist influence more directly in Africa, Libya replaced Israeli technical aid with its own financial aid in Black Africa.

\section{THE JAMAHIRIYA AND CHAD:}

The events in Chad may be viewed within the context of American efforts to destabilize the Jamahiriya. American policy aimed at discrediting Libya in the eyes of the world, to pressure some African countries to seek closer relations with the West and to persuade France for a more interventionist strategy. Although Libya's support was for the internationallyrecognized government of Chad, the Western media presented it as a sinister move on the part of the Jamahiriya. Libyan presence in Chad took place in the "interventionist climate" created by France and the United States. The French forces were in the Central African Republic, Cameroon, Senegal and Gabon. Foreign intervention was multi-dimensional in Chad. France militarily intervented, and there certainly was Egyption involvement. The major part of the Egyptian army faced Libya rather than Israel..$^{58}$ The U.S. seems less interested in Chad than the opportunity the crisis offers to criticise Libya. Reagan's statement that Chad was not their main sphere of influence but that of France is a challenge to the Third World countries, which reject the argument of dividing the nonaligned states into various spheres. ${ }^{59}$

Over the past few years, the United States had refrained from overt intervention in North Africa, entrusting the policing of Western interests there to France. In addition to the strategic Djibouti at the mouth of the Red Sea, France had troops in a number of African countries. It also has special intervention units - the 11th Parachute Division (in Pau in Southern France), the 9th Marine Infantry Division and the Foreign Legion. Three parachute regiments are also on the alert in Southern France and Corsica.

France realizes the importance of Chad's geo-strategic position. Its interest extends also to a concern for continued control of uranium in neighbouring Niger and in Chad as well. Although one of the ten least developed countries in the world, it is known to be rich in deposits of

53 International Herald Tribune, January 19, 1981.

¿9 U.N. Chronicle, New York, Vol. XX, No. 9 (October 1883), p. 14. 
oil, uranium and some other precious metals. Whereever France has mineral interests its African policy may be surnmed up as a series of "protectorates". Niger's rich uranium provides about one-fifth of the need for France's nuclear program. French advisers are training Niger's armed forces.

In terms of its rivalry with France, Libya is challenging a historical obstacle to full African independence. Libyan leadership still wants to have good relations with France on account of the latter's somewhat independent policy with regard to the United States. For some time, the U.S. and France were at loggerheads over their respective assessments of the "Libyan threat". When the French President François Mitterand finally mounted Operation Sting-Ray, this was the largest military intervention of France since the Algerian war. France has deliberately misinterpreted Libya's relations with Chad to send more troops to West Africa. Though blamed for the military coups in Upper Volta and Guinea-Bissau, no evidence of Libyan involvement could have been showed. Accusing statements by a French Minister, made in Togo, Cameroon and the Central African Republic, to create the impression that these African states, reasonably close to Libya, entertained fears of the Jamahiriya, seem actually intended to excuse French supply of arms to the neighbouring states.

Chad has been going through a state of civil war since independence. It is a heterogenous country, both in terms of race and religion: the north and east are inhabited by Moslem Arabs and the south by Catholic Blacks. The frontiers, subject to ethnical disputes, were drawn by the colonialists to suit their agreements. It is worth remembering at this point that the Ottoman Empire treated northern Chad as part of its North African provinces. The Libyans considered the addition of the Aouzou strip along the border to their territory in 1975 as a rectification, disputed even by the Italians. In the $1920 \mathrm{~s}$ and the $1930 \mathrm{~s}$, the Libyan resistance fighters found refuge in Chad, where there has been long-standing ethnic ties as well. $^{60}$ For Libyans, neighbouring Chad is a place where their fathers and grand-fathers took refuge during the Italian invasion. ${ }^{61}$ They believe that Chad has a Moslem majority, the Mahamid Tribe being of Libyan origin.

${ }^{60}$ Kaddafi stated in Tripoli on January 20, 1981 that there was an old historical interaction between the peoples of Libya and Chad and that Arab-Islamic culture prevailed in that neiphlbouring country. Colin Legum, "The Crisis over Chad," Africa Contemporary Record: 1930-1981, New York, Africana, 1982, p. 441.

61 Socialist People's Libyan Arab Jamahiriya. The Jamahiriya and Peace in Chad: 1980-1981. Tripoli, Public Establishment for Publishing, Distributing and Advertising, 1982, p. 12. 
When Chad was granted its independence in 1960, it became a Republic within the French community. François Tombalbaye, its first President, who turned to be an autocratic ruler, pursued a policy of repression, felt especially by the Moslem population. He imposed the absolute domination of non-Moslem tribes, particularly of his own Sara tribe. ${ }^{62}$ The National Liberation Front (Frolinat) was formed in 1966 with the declared aim to overthrow this régime.63 Goukouni Weddeye (also spelled as Queddei), Chairman of the Frolinat, stated that no school or hospital had been opened in Chad in the twenty years since independence and that there were only five trained accountants in the country. ${ }^{64}$

The struggle continued until Frolinat marched towards the capital and Felix Maloum, who had replaced Tombalbaye, was forced to escape. A Chad National Unity Pact was signed on August 21, 1979, and Weddeye became Prime Minister of the provisional government. Hussein Hibré, a member of the Qira'an tribe, was made Minister of Defence. The latter used his position as Defence Minister to appoint himself as Premier by force. When fighting between his forces and those of the government spread all over the country, the legitimate government, depending on the mutual defence agreement (1980) between Chad and Libya, sought help from its northern neighbour. From the legal view, the Libyan case was irrefutable. The President of the legitimate government had asked for the assistance of another legitimate government for purposes of defence. There is no evidence to support the American' allegation that Libya has used Chad as a staging area for thrusts against other lightly defended states. Principally American sources had claimed that Chad was the first stage in Kaddafi's plan of further penetration into Africa, that Libya was a "Soviet long arm" in the continent and that Libya intended to use Chad to topple the régime in Sudan and, allied with Ethiopia and South Yemen, to encircle Egypt. A Christian Science Monitor report ${ }^{65}$ described Libya in Chad as a "Soviet Trojan horse." Another report ${ }^{66}$ suggested that several neighbours of Libya would probably welcome American influence to frustrate "Libyan expansion". There were no Soviet advisors in Chad; not a single Western reporter referred to any Soviet personnel there. Altinough

62 M. Zarkovic, "Chad and Libya," Review of International Affairs, Belgrade, No. 671 (March 20, 1978), p. 34.

${ }^{63} \mathrm{R}$. Buitenhuijs, Le Frolinat et les révoltes populaires du Tchad: 1965-1976. The Hague, Paris, New York, 1978.

54 Yuri Bochkarkov, "No Peace in N'djamena." New Times, Moscow, (May 1980). p. 24.

65 March 31, 1981.

f6 November 20, 1880. 
some circles ${ }^{67}$ alleged that Kaddafi had plans for "a greater Saharan empire", they produced no evidence to support this assumption. An International Herald Tribune editorial agreed that the French could "arrange" an intervention in the same area. In other words, France could pursue a neo-colonialist policy in central Africa, but Libya, itself a country of that continent, could not entertain plans of unity with neighbours.

When the rebel forces of Habre were defeated, the Libyan forces withdrew from Chad - again at the request of the legitimate Chad Government, thus falsifying claims of those who doubted Libya's intentions. ${ }^{\text {. }}$ They withdrew after accomplishing the mission of restoring security and after building much-needed roads and schools, digging wells and bringing electricity to some areas. Even circles unsympathetic to Libya should concede that Libyan presence in Chad has been legitimate, and that neighbouring Libya is perhaps the only country able and willing to provide the financial means to get Chad onto its feet. When the war ended, there was very little about this in the world press, as well as its favourable effects on the country. While Libya was pulling its troops from Chad, the United States and France maintained their military presence in a number of states around Libya. A declaration of unity between Libya and Chad was announced a few weeks after the defeat of the rebels. The proposed merger gave Libya's critics an opportunity to draw unfair parallels and accuse Tripoli of being a "pawn of the Kremlin".

During the vacuum, however, between the Libyan withdrawal and the advent of the African peacekeeping forces, Habre seized a large portion of Chad territory, with ample military assistance from Egypt and Sudan, and through them from the United States. The lawful government, which went into the counter-offensive, was supported by Libya and France for different reasons. Libya helped the lawful government because it wanted to prevent Chad from becoming what it would regard as a bastion of the U.S. and the African reactionary régimes, which would threaten Libya's. security. France considered the same government as a better guarantee of her interests in Chad than Habré. To ensure Habrés political survival, beginning with 1981 "through the United States Central Intelligence Agency (CIA) - sponsored networks running from Langley to Cairo, from Cairo to Khartoum and ultimately to Abeche and beyond, automatic weapons, ammunition, vehicles, fatigues and boots and, above all, cash flowed into Habré's hands." ${ }^{19}$ Making use of these resources, Habré cam-

67 International Herald Tribune, January 8, 1981.

* Zarko Militinovic, "The Continuing Drama in Chad," Review of International Affairs, Belgrade, No. 770 (May 5, 1982), p. 22.

69 René Lemarchand, "Chad: the Road to Partition." Current History, Pennsylvania, Pa., Vol. 83, No. 491 (March 1984), p. 116. 
paigned against the government forces, capturing Ndjamena in June 1982. The U.S. seemed well disposed towards the rebel suggestions to sell them American arms to defeat the government forces. One may repeat with Abbas and Hyman here that this is "precisely the charge that is continously levelled through the media at Libya's foreign policy."70 The routing of Goukouni's forces. and the transformation of his Transitional National Union Government (GUNT) into a "rebel government-in-exile" gave Libya the same opportunity to back it as the U.S. had covertly supported Habré. Although the U.S. now states that Habré's government is the legimate one, the Libyan question, posed during the debates in the U.N. Security Council in August 1983, as to "where has the conscience of the American Administration been in 1980, when Habré's forces had attacked the legitimate Government of Chad"11 can only remain unanswered.

\section{KADDAFI - A PERSONIFICATION:}

Muammer al-Kaddafi's name is being used interchangeably with that of Libya. Whatever is attributed to Kaddafi is ascribed to Libya. To try to explain a country's foreign policy solely or largely in terms of the government's present leader is to overlook other important issues that shape it. Nevertheless, such personification continues: For instance, U.S. News and World Report described Kaddafi as "fanatic". ${ }^{22}$ Claire Sterling denounced him as "a murderer, a maniac - and Moscow's man". ${ }^{73}$ He was termed "adventurist", a "militarist", an "expansionist" - at least, "ambitious". An American writer proclaimed that "no one liked the colonel"." Sterling felt free to tie the fascist bombing at Bologna in 1980 to Libya. Kaddafi was accused of being a Soviet pawn, a Nazi and fascist. The Economist spoke of him as "the Duce of Libya".

The foreign policy of Muammer al-Kaddafi is too often described as unpredictable and whimsical. He is accused of seeing "imperial dreams". ${ }^{76}$ He is out for "a new power play in Africa"."

\footnotetext{
70 Abbas and Hyman, op. cir., p. 25.

71 U.N. Chronicle, New York, Vol. XX, No. 9 (October 1983), p. 13.

T2 Decembar 1, 1980.

73 Claire Sterling, The Terror Network, New York, Holt, Rinehart and Winston, 1981.

74 Daniel Pipes, "No One Likes the Colonel," The American Spectator, 14, 3 (March 1981), pp. 18-22.

75 February 3, 1981.

79 "Quadhafi's Imperial Dream," International Herald Tribune, January 12, 1981.

7 David Richarsison, "Behind Libya's New Power Play in Africa," U.S. News and World Repo:t. January 26, 1981.
} 
Kaddafi and his associates, as followers of the Egyptian President Gamal Abd al-Nasser, declared themselves as devoted to the goals of antiimperialism, Arab socialism and Arab unity. By late 1972, Kaddafi started contemplating hypothesis within the general framework of anti-colonialism and nationalism which came to be known as the Third Universal Theory. He proposed this concept as an alternative to both capitalism and communism. Kaddafi has been critical of the American and the Soviet forms of government, but has maintained commercial relations with both, buying Western and Soviet technology. His concept of jihad (holy war) as a contribution to liberate the world from imperialism had led him to support liberation movements publicly.

It is no secret that the U.S. wants to see the downfall of Kaddafi and the Jamahiriya régime. It is generally believed that the Special Operations Division of the CIA, set up in early 1960, is busy organizing the overthrow of governments which the United States finds not to its liking. A Mediterranean naval task force with enough carrier-launcher aircraft and artillery, special units to be flown from near-by bases and expatriates to infiltrate across borders are the three types of forces that the U.S. plans to rely on. A propaganda campaign, to discredit Libya in the eyes of world putilic opinion, seems to be a prerequisite for future military intervention. Since the Second World War, the United States intervened militarily in Greece (1946-1949), Paraguay (1947), the Philippines (19481953), Guatemala (1954), Lebanon (1958), Cuba (1961), Congo (1964), Panama (1964), Vietnam (1964-1973), Laos (1964-1973), the Dominican Republic (1965), Cambodia (1970-1975), Bolivia, Chile and El Salvador (19711973), Lebanon (1982) and Grenada (1983). Similarly, the CIA has also planned anti-government plots in the Libyan armed forces. ${ }^{78}$ There were also reports that Anwar al-Sadat of Egypt had planned Kaddafi's assassination. ${ }^{79}$

\section{CONCLUSION:}

Official U.S. pronouncements and the Western media in general do not portray an accurate picture of the world. Otherwise, the need to "decolonize information" $" 80$ and the UNESCO conferences, out of which the New International Information Order was projected, would have been dispensable.

\footnotetext{
${ }_{78}$ Anderson, op. cit., p. 530.

79 Abbas and Hyman, op. cit., Vol. II, pp. 63-C4.

29 F. Lwanyantika Masha. "Decolonizing Information: Towards New World Information and Communication Order (NWICO)," in Political Communication and Persuasion, Vol. I, No. 4, Crane, Russak and Co., 1982, pp. 337-342.
} 
Libya has a vision of a new world, which may or may not coincide with those of others. Its objectives are summarized as "freedom; socialism and. unity". There will be - and there has been- objections to Libyan interpretations and applications of these concept. The Libyan society, on the other hand, is being restructered - perhaps beyond a point of no return. A new generation is growing with the Revolution, and the expectations of the average Libyan are met. What is being achieved is impressive. People have income, food, decent homes, education opportunities and health services. Libyans, who discuss national and international affairs at grass roots level, have the feeling that it is not the state, but the people's committees and the people's congresses that make the decision. The people support Libya's foreign policies. A pro-Western platform would not be acceptable by the masses even if the leadership had opted for it. Such a preference would contradict the lessons Libya drew from its own history. One of the consequences may be opposition to President Reagan's diplomacy. The Libyan people support liberation movements, but oppose terrorism. They realize that oil, as a non-renewal resource, is a matter of bitter international bargaining and that most of the revenue drived from it is utilized to meet their rising expectations. They believe in Arab unity and the centrality of the issue of Palestine in the complex gamut of Middle Eastern problems. They approve of the legitimacy of the Libyan role in the Chad controversy. Libya is not obsessed, like the Reagan Administration, with East-West confrontation. In the eyes of that country, the United States is a follower in the footsteps of the old European colonial powers. Fairer reporting about Libya would be better odds for a peaceful world. 